\title{
Editorial: Multilingual Humour in Translation
}

\author{
Margherita Dore \\ University of Rome "La Sapienza" \\ margherita@uniroma1.it
}

Traveling and communicating in today's globalised world have become much faster, easier and cheaper. Consequently, the chances of having people moving from one country to another have also increased. Although it very often happens that people move from developing countries to more affluent ones, it is also true that many people within wealthy communities may decide to live in another country for study or work-related purposes (cf. Dore 2018, 2019). Consequently, many of us nowadays live in societies that can be described as melting pots, in which people from different cultures often speak two or more languages. As a result, those who are part of these multilingual communities often use code-switching and code-mixing to express and assert their bi/multi-cultural identity (Monti 2016: 69).

It is therefore unsurprising that this phenomenon, which stems from language contact, is currently reflected in literary and audiovisual texts. This type of fictional representation of multilingual communities is certainly not novel. Shakespeare made extensive use of multilingualism for both comic and non-comic purposes (Delabastita 2002, 2005). Likewise, the use of code-switching and code-mixing has always been a relatively constant feature of audiovisual works over the years (De Bonis 2015). However, it is the turn of the new century and millennium that has brought this phenomenon to the fore. Audiovisual works such as films and TV series have nowadays become available via traditional means (i.e. cinema and TV) as well as via on-demand streaming platforms such as Netflix, Hulu, Amazon Video and so forth. In addition, they can be easily accessed in a host of different formats, e.g. in the original version, subtitled, dubbed, etc. This multifaceted mediascape has also allowed producers to create new and complex audiovisual content, which often attempts to capture the present heterogeneous reality.

Writers and scriptwriters have exploited heterolingualism to convey idiosyncratic features regarding the characters and specific images of the fictional world they inhabit. As Hodson (2014: 5-6) rightly argues, "the way in which a character speaks will correlate directly with their social and geographical background, and as audiences or readers we are accustomed to using these clues to help us understand the film or novel." However, multilingualism can serve a host of other purposes. Along with character configuration, Delabastita \& Grutman (2005a: 16) point out that multilingualism in fictional texts creates an "inter-play" that can be used to express conflict, spatial opposition, mimesis, and suspense management. Furthermore, these authors observe that interlingual misunderstandings and mistranslations can be exploited for comic effect. Put more simply, multilingual humour hinges upon the inter-play of two or more languages, which are exploited to create contrast and trigger what Chiaro (2018) describes as "comic confusion." The resulting situations are often paradoxical or grotesque (Chiaro 2014; 
De Bonis 2014). The importance of such situations within a text (its story and discourse) certainly cannot be overlooked, as the contributions in this special issue show.

Multilingualism and its exploitation within literary and non-literary texts have been the centre of a good deal of research over the years. An overview would be impossible here and it is beyond the scope of this introduction (however, see, for instance, Mackey 1993; Toda 2005; Lippi-Green 2012). The main interest of this volume is how this phenomenon is used for the purpose of humour and how it can be tackled in translation. Within Translation Studies, multilingualism has indeed attracted the attention of many scholars who have problematised and investigated the feasibility of conveying humour through translation. Many contributions in Delabastita \& Grutman's (2005b) special issue of Linguistica Antverpiensia on "Fictionalising Translation and Multilingualism" testify to the widespread use of heterolingualism in fictional texts and the way they have been or can be tackled in translation. As argued by Meylaerts (2006: 12), this growing interest is certainly a good sign as it helps to grasp "the complex functions of heterolingualism in/and translation." Recent studies focusing on language variation in general (e.g. Geyer \& Dore 2009, forthcoming; Marrano et al. 2009; Nadiani \& Rundle 2012; Brenner \& Helin 2016) and heteroglossia in particular have certainly contributed to the continuous explorations of this linguistic and cultural aspect of language contact and the issues linked to its translation (Grutman 2006).

Within Audiovisual Translation, several scholars have devoted much attention to the way the underlying original message is conveyed depending on the translation mode employed (e.g. dubbing, subtitling), the type of strategies, procedures and manipulative processes employed and the possible reasons behind these choices (cf. O'Sallivan 2007, 2011; Bleichenbacher 2008; Chiaro 2010; Corrius and Zabalbeascoa 2011; Díaz Cintas 2011; Minutella 2012; Heiss 2014; Chiaro 2018, just to name a few). Understanding the main features and tendencies that the translation of language variation brings about within audiovisual products is also the main focus of major research projects such as TRAFILM ${ }^{1}$ (cf. also Corrius et al., forthcoming).

With the exceptions mentioned above, it may be maintained with a measure of confidence that only a part of this research has been devoted to the exploitation of heteroglossia for humorous purposes and how it can be (or is) transferred across language and culture. Hence, this special issue seeks to further enhance scholarly research in multilingual humour and translation by exploring this phenomenon from different perspectives. As it may be readily noticed, a significant number of papers in this thematic volume concentrate on the AVT of multilingual humour. For instance, Delia Chiaro \& Giuseppe De Bonis open this special issue with their study titled "An Austrian in Hollywood: The representation of foreigners in the films of Billy Wilder." These authors' interest in Billy Wilder's films lies in the films' frequent use of different languages as a tool to show the clash between two (or more) dissimilar cultures. As they demonstrate, this collision triggers humour on many levels by exploiting the multi-modal portrayals of diverse "foreigners," namely Germans, Russians, French and Italians. Their analysis focuses particularly on the comic collision of two or more languages and the way Wilder exploits humour to highlight the absurdity of cultural difference.

Continuing to explore multilingualism in audiovisual works produced in the previous century, Monika Wozniak analyses Stanisław Lenartowicz's 1964 film titled Giuseppe in Warsaw. The film features an Italian soldier stranded in Poland after the end of World War II. Translation, mistranslation, pseudo-translation and mock translation figure conspicuously in the movie, thus showing a series of clashes between Polish, German and Italian languages in

\footnotetext{
${ }^{1}$ The TRAFILM project is a research project funded by the Spanish government that has been developed by a group of scholars based at the Pompeu Fabra University, Barcelona. It investigates the features and tendencies that arise from rendering linguistic diversity for dubbing, subtitling and accessibility; more information can be obtained visiting the project's website: http://trafilm.net (last accessed: 06/03/2019).
} 
the most improbable combinations. Wozniak's analysis discusses the many mechanisms used in the film to convey humour via multilingualism. Most importantly, the author examines the original film against its subtitled version in Italian to verify how the dynamics of humour change in the case of L3, which becomes L1 in translation, meaning Italian. She convincingly shows how the translation process leads to the subversion of the target audience's point of view, because it identifies with the protagonist rather than the Polish characters in the movie.

Like Wozniak, Giulia Magazzù's analysis deals with the case when L3 in the source text coincides with L1 of the target text. In particular, this author concentrates on the Big Night (Campbell Scott \& Stanley Tucci 1992) a dramedy in which the use of Italian as L3 is an essential part of the film's narrative and its humour. The comparative analysis of the original and Italian dubbed version aims specifically at understanding how the dialogues have been conveyed and especially how multilingual humour and the stereotypes it brings about regarding the Italian language and culture are transferred in translation. As the author explains, the Italian dubbing loses the bilingualism of the scenes and so in part fails to convey the original idea of opposing misperceptions and stereotypes regarding Italians in the USA.

Moving into the $21^{\text {st }}$ century, Margherita Dore's analysis focuses on the North American mockumentary (or docucomedy) Modern Family (Christopher Lloyd \& Steven Levitan 20092019) and its dubbed Italian version. This TV series aims to truly embrace diversity by showing the extended family of Jay Pritchett, which comprises a gay son and his partner. Most importantly, this modern family includes Jay's second wife Gloria Delgado, a young and beautiful Colombian woman who often code-switches or code-mixes English and Spanish (with a marked Colombian accent), thus creating moments of pure comedy. This analysis confirms the current tendency of Italian dubbing to render otherness in the target text. This more innovative approach may be justified by the genre and scope of the programme and facilitated by the fact that L2 and L3 are closely related languages. That said, the author shows that the functional manipulation of the text, which seeks to privilege the intended effect, successfully conveys vernacular matching, especially when it is used for humorous purposes.

The remainder of the papers in this volume focuses on the translation of multilingual humour in literary texts. Cristina Vezzaro \& Katrien Lievois deal with the Dutch and Italian translations of Laroui's works, in which the two central features of his writing, that is, humour and multilingualism, are strictly related. These features of Laroui's prose allow him to present, in axiological opposition, different viewpoints that cross cultures, nationalities and social hierarchies. The analysis of Le Jour où Malika ne s'est pas mariée and Une année chez les Français has allowed these authors to determine how puns are created through the use of different languages or loanwords. The comparative examination of the original and the Dutch and Italian target texts demonstrates that the humour conveyed via the use of L3 in the source text is rendered in the target texts by direct transfer, adaptation to the target language or by keeping it via intertextual or paratextual elements. In addition, sometimes the punning elements have been replaced altogether. In general, both translators have shown a good deal of creativity, which is certainly beneficial to their professional practice and the text itself.

Mary Frank's study is a reflection of the possible methods of translating a text containing two varieties of German into English. She concentrates on Ottokar Domma's Der brave Schüler Ottokar [The Good Schoolboy Ottokar]. Domma's stories are about a schoolboy growing up in the German Democratic Republic (GDR) in the 1960s. He creates a zone of friction between child narrator Ottokar's everyday German and the language of GDR officialdom ("official discourse"). Frank shows that following the conventional method of translating a literary text into English does not allow this satire to be conveyed to the reader. Hence, she proposes two alternative translational methods: "thick" and creative. They both demonstrate how helpful or, in some cases, necessary it is to adopt a broad understanding of 
"translation" in respect of texts that exploit multilingualism for humorous purposes. The introduction of multimodality can help to open up heterolingual humour for speakers of other languages.

Roman Ivashkiv's work concludes this special issue by investigating how transmetic, multilingual and intertextual puns in Pelevin's novel Generation " $P$ " have been translated into English, German, Polish, Spanish, and French. The author's analysis of some examples taken from the source text shows the complexities underlying the creation of puns that rely particularly on code-mixing and the difficulties connected to their transfer into other languages. In addition, the author explores the processes at work when the novelist exploits wordplay to evoke intertext(s), which in turn may impede translation or make this endeavour apparently impossible. Nonetheless, the analysis of multiple target texts and the different approaches used therein proves that creativity can often open alternative avenues for interesting solutions. The translators' roles and tasks are therefore underscored and the concept of (un)translatability is debated in general terms and in relation to punning in particular, since this notion still underpins the entire discipline of translation studies and yet remains its most daunting philosophical problem.

To conclude, it is hoped that the inductive research presented in this issue on multilingual humour and/in translation has contributed to shedding light on the procedure that can be implemented to preserve this important feature of literary and audiovisual works. It may also serve as a source of inspiration for future scholarly research carried out by both established and young scholars interested in this topic.

\section{References}

Bleichenbacher, L. (2008). Multilingualism in the Movies: Hollywood Characters and their Language Choices. Tübingen: Francke Verlag.

Brenner, K. \& Helin, I. (2016). 'The translation of Dialects and Multimedia III'. Special issue of InTRAlinea.

Chiaro, D. (2010). 'Found in translation: cross-talk as a form of humour', in Valero-Garcés, C. (ed.), Dimensions of Humor: Explorations in Linguistics, Literature, Cultural Studies and Translation, València: Universitat de València, pp. 33-54.

Chiaro, D. (2014). 'Mimesis, reality and fictitious intermediation', in Antonini, R. \& Bucaria, C. (eds.) Non-professional Interpreting in the Media, Frankfurt am Main: Peter Lang, pp. $23-42$.

Chiaro, D. (2018). 'Cross-languaging romance on screen', in Abend-David, D. (ed.), Representing Translation, New York: Benjamins.

Corrius, M. \& Zabalbeascoa, P. (2011). 'Language variation in source texts and their translations: The case of L3 in film translation'. Target, 23 (1), pp. 113-130.

Corrius, M., Espasa, E. \& Zabalbeascoa, P. (forthcoming). Multilingualism and Audiovisual Translation, Frankfurt am Main: Peter Lang.

De Bonis, G. (2014). 'Commedia in scompiglio: One, Two, Three. Il multilinguismo come veicolo di umorismo', in De Rosa, G. L., Bianchi, F., De Laurentiis, A. \& Perego, E. (eds.), Translating Humour in Audiovisual Texts, Bern - Berlin - Bruxelles - Frankfurt am Main - New York - Oxford - Wien: Peter Lang, pp. 189-214.

De Bonis, G. (2015). 'Translating multilingualism in film: A case study on Le concert'. New Voices in Translation Studies, 12 (2015). IPCITI 2013 Proceedings. Guest-edited by P. Castillo, P. Karanasiou, M. Shamy \& L. Williamson, pp. 50-71. 
Delabastita, D. (2002). 'A great feast of languages. Shakespeare's multilingual comedy in "King Henry V" and the Translator'. The Translator, 8 (2): 303-340.

Delabastita, D. (2005). 'Cross-language comedy in Shakespeare', in Chiaro, D. (ed.), Humour and Translation. Special issue of HUMOR - International Journal of Humor Research $18(2), 161-184$.

Delabastita D. \& Grutman, R. (2005a). 'Introduction: fictional representations of multilingualism and translation', in Delabastita, D. \& Grutman, R. (eds.), Fictionalising Translation and Multilingualism. Special issue of Linguistica Antverpiensia 4, pp. 11-34.

Delabastita, D. \& Grutman, R. (2005b). Fictionalising Translation and Multilingualism. Special Issue of Linguistica Antverpiensia 4.

Díaz Cintas, J. (2011). 'Dealing with multilingual films in audiovisual translation', in Pöcki, W., Ohnheiser, I. \& P. Sandrini (eds.), Translation Sprachvariation Mehrsprachigkeit, Frankfurt: Peter Lang, pp. 215-233.

Dore, M. (2009). 'Target language influences over source texts: A novel dubbing approach in The Simpsons, first season', in Federico Federici (ed.), Translating Regionalised Voices for Audiovisual, Roma: Aracne editrice, pp. 136-156.

Dore, M. (2018). 'Laughing at you or laughing with you? Humour negotiation and intercultural stand-up comedy', in Tsakona, V. \& Chovanec, J. (eds.), Creating and Negotiating Humor in Everyday Interactions, Amsterdam: John Benjamins, pp. 105126.

Dore, M. (2019). 'Food and translation in Montalbano', in Balirano, G. \& Guzzo, S. (eds.), Food Across Cultures Linguistic Insights in Transcultural Tastes, Houndmills: Palgrave Macmillan, pp. 23-42.

Dore, M. (forthcoming). 'Revoicing otherness and stereotypes via dialects and accents in Disney's Zootopia and its Italian dubbed version', in Gueyer, K. \& Dore, M. (forthcoming). New Perspectives in Dialects and Multimedia. Special issue of InTRAlinea.

Geyer, K. \& Dore, M. (forthcoming). New Perspectives in Dialects and Multimedia. Special issue of InTRAlinea.

Grutman, R. (2006). 'Refraction and recognition: Literary multilingualism in translation'. Target 18 (1), pp. 17-47.

Heiss, C. (2014). 'Multilingual films and integration? What role does film translation play?', in Abend-David, D. (ed.) Media and Translation: An Interdisciplinary Approach, London: Bloomsbury.

Hodson, J. (2014). Dialect in Film and Literature. Houndmills: Palgrave MacMillan.

Lippi-Green, R. (2012). English with an Accent. New York: Routledge.

Mackey, W. (1993). 'Literary diglossia, biculturalism and cosmopolitanism in literature'. Visible Language 27(1/2), pp. 41-66.

Marrano, G. M., Nadiani, G. \& Rundle, C. (2009). 'The translation of Dialects and Multimedia'. Special issue of InTRAlinea.

Meylaerts, R. (2006). 'Heterolingualism in/and translation. How legitimate are the Other and his/her language? An Introduction.' Target 18 (1), pp. 1-15.

Minutella, V. (2012). 'You fancying your gora coach is okay with me': Translating multilingual films for an Italian audience', in Remael, A., Orero, P. \& Carroll, M. (eds). Audiovisual Translation and Media Accessibility at the Crossroads. Media for All 3. Amsterdam: Rodopi, pp. 313-334.

Monti, S. (2016). 'Reconstructing, reinterpreting and renarrating code-switching in the Italian dubbed version of British and American multilingual films', in Díaz-Cintas, J. et al. 
(2016), Idiological Manipulation in Audiovisual Translation. Special issue of Altre Modernità, pp. 68-91.

Nadiani. G. \& Rundle, C. (2012). 'The translation of Dialects and Multimedia II'. Special issue of InTRAlinea.

O'Sullivan, C. (2007). 'Multilingualism at the multiplex: a new audience for screen translation?'. Linguistica Antverpiensia 6, pp. 81-95.

O’Sullivan, C. (2011). Translating Popular Film. Basingstoke: Palgrave Macmillan.

Toda, F. (2005) 'Multilingualism, language contact and translation in Walter Scott's Scottish novels'. In Delabastita, D. \& Grutman, R. (eds.), Fictionalising Translation and Multilingualism. Special issue of Linguistica Antverpiensia 4, pp. 113-138. 